日臨外医会誌 $58(9) ， 1963-1968 ， 1997$

原

進行胃癌に対する腹腔鏡下進行度診断

\begin{tabular}{|c|c|c|c|c|c|c|c|c|c|c|c|c|c|}
\hline \multicolumn{14}{|c|}{ 大阪大学第 2 外科 } \\
\hline 野 & 雅 & 彦 & 塩 & 崎 & 均 & 村 & 田 & 厚 & 夫 & 井 & 上 & 雅 & 智 \\
\hline 本 & 貢 & 嗣 & 土 & 岐 & 祐一郎 & 谷 & 口 & 仁 & 章 & 門 & 田 & 守 & ) \\
\hline
\end{tabular}

術前画像検查で T3または $\mathrm{P}(+)$ の疑われた進行胃癌患者16例に対して術前腹腔鏡検 查を行い，その有用性を検討した，臍下部と左季肋部より 2 本のトロッカーを挿入して 腹腔内を観察し，必要に応して術中洗浄細胞診，生検を行った。術前画像診断と腹腔鏡 診断との乘離率を各因子別に見ると，T因子では16例中 6 例 (37.5\%)，P因子で 7 例 (43.8\%)，H 因子 1 例 (6.3\%)，N 因子 1 例 (6.3\%)であった。これらを総合すると腹 腔鏡検查後 downstagng となったものが16例中 3 例(18.8\%)，逆に upstaging となった ものが 4 例 $(25.0 \%)$, stageの変わらなかったもの 9 例（56.3\%）であった。 16 例中 8 例は治瘾切除可能と診断し全例に根治度 B の手術が行えた。初回非切除となった 8 例の うち 4 例では腹腔鏡検査により不要な開腹術が回避できた．以上より診断的腹腔鏡は進 行胃癌の術前検查として有用であると思われた。

索引用語：進行胃癌, 術前診断, 腹媓鏡, 進行度診断

はじめに

近年, 光学機器特にビデオカメラ,テレビモニター 等の発達により腹腔鏡下手術はますます盛んとなり, その技術的進歩には目をみはるものがある。またその 対象となる疾患も急速に広がりつつある。現在, 腹腔 鏡は治療面への応用ばかりが脚光を浴びているきらい があるが，従来，腹腔鏡は治療の分野よりもむしろ診 断のために開発されたものであり，その技術的な進歩 は当然，診断面においても生かされてしかるべきであ る.

さて胃癌の診断, 特にその進行度診断は現在, 胃透 視, 内視鏡, $\mathrm{CT}$, 超音波検査, MRI 等の検査によって いるが，その診断能には限界があり，特に腹膜播種や 他臓器浸潤が疑われる高度進行胃癌では開腹したもの の非切除になる確率が高い. 進行癌で開腹術を行った 患者のうち $15.8 \sim 34.3 \%$ 単開腹のみに終わってお り $^{122}$, その合併症は13〜23\%, 死亡率は10～ $21.2 \%$ と 報告されている(1314).したがってこれらの不必要な開 腹術を避けるためにはさらに正確な術前進行度診断が 必要である。また, 近年, 初回切除不能の局所進行胃 癌に対して neoadjuvant chemotherapy を施行するこ

1996年10月25日受付 1997年 6 月11日採用
とで切除率の向上と生存期間の延長が見られたという 報告がある ${ }^{576)}$. しかしながらこれら化学療法の効果判 定や手術適応の決定にはやはり正確な進行度の診断が 必要である。

われわれは, 高度進行胃癌患者の術前進行度診断に 腹腔鏡検査がどの程度有効であるかを検討したのでこ こに報告する。

\section{対象および方法}

平成 7 年 1 月より平成 8 月 7 月までの間に大阪大学 第 2 外科に入院した胃癌患者のうち術前画像検查にて T3以上または $\mathrm{P}(+)$ が疑われた高度進行胃癌患者の うちインフォームドコンセントの得られた16例を対象 とした，画像検査としては，胃透視，胃内視鏡，腹部 単純ちよび造影 CT を全例にルーチンに行い，必要に 応じて MRI，超音波エコー，骨シンチを施行した， 16 例中， 3 例が肝または膵への浸潤あり（T4）と診断さ れ， 2 例が P1， 1 例が P2 (Kruckenberg tumor) と 診断された。また，4例に大動脈周囲のリンパ節への 転移 (N4)，2 例に遠隔転移 (骨転移と胸膜転移)を認 めた。

7 例は全身麻酔, 9 例は局所麻酔下に腹腔鏡検查を 施行した。臍下部より $10 \mathrm{~mm}$ のトロッカー, 左季肋部 より $5 \mathrm{~mm}$ のトロッカーを挿入し,フジノン社製フレキ 
シブルタイプの腹腔鏡にて腹腔内の観察を行った。観 察は両横隔膜下面, 壁側腹膜, 腸間膜, 大小網への腹 膜播種の有無, 腹水の貯留, 肝表面の転移の有無, 胃

\section{表 1 患者背景}

\begin{tabular}{|c|c|c|c|}
\hline \multicolumn{2}{|c|}{ 年龄 } & & \\
\hline \multicolumn{2}{|c|}{ 性別 (男/女) } & \multicolumn{2}{|c|}{$7 / 9$} \\
\hline \multirow[t]{7}{*}{ 占拠部位 } & 1 領域 & 4 & $(25.0 \%)$ \\
\hline & 2 領域 & 8 & $(50.0 \%)$ \\
\hline & 3 領域 & 4 & $(25.0 \%)$ \\
\hline & 小弯中心 & 9 & $(56.3 \%)$ \\
\hline & 前壁中心 & 1 & $(6.3 \%)$ \\
\hline & 後壁中心 & 2 & $(12.5 \%)$ \\
\hline & 全周 & 4 & $(25.0 \%)$ \\
\hline \multirow[t]{3}{*}{ 肉眼型 } & Type 2 & 1 & $(6.3 \%)$ \\
\hline & Type 3 & 8 & $(50.0 \%)$ \\
\hline & Type 4 & 7 & $(43.8 \%)$ \\
\hline \multirow[t]{7}{*}{ 組織型 } & por & 5 & $(31.3 \%)$ \\
\hline & sig & 4 & $(25.0 \%)$ \\
\hline & muc & 2 & $(12.5 \%)$ \\
\hline & tub1 & 2 & $(12.5 \%)$ \\
\hline & tub2 & 1 & $(6.3 \%)$ \\
\hline & pap & 1 & $(6.3 \%)$ \\
\hline & unknown & 1 & $(6.3 \%)$ \\
\hline \multirow[t]{5}{*}{ 進行度 } & Stage II & 4 & $(25.0 \%)$ \\
\hline & Stage III a & 4 & $(25.0 \%)$ \\
\hline & Stage III b & 1 & $(6.3 \%)$ \\
\hline & Stage IV a & 1 & $\left(6.3^{\circ} \%\right)$ \\
\hline & Stage IV b & 6 & $(37.5 \%)$ \\
\hline
\end{tabular}

槳膜面への浸潤，胃周辺のリンパ節の腫大等について 検索した。肝浸潤の有無についてはエンドリトラクタ で肝左葉を挙上させ直接観察した。膵浸潤の有無につ いては全麻下の場合は直接網襄内に腹腔鏡を挿入し観 察したが, 局麻下の場合は腫瘍の可動性から判断した。 原則として術中洗浄細胞診を行い，腹膜播種と思われ る結節のある場合は生検を施行した。

\section{結果}

\section{1. 背景因子}

対象となった患者の背景因子は表 1 に示すように， 年龄は27葴から77歳, 平均 54.6 歳, 男女比 $7: 9$ であっ た. 腫場の占拠部位は 2 領域以上にまたがるものが12 例で，うち 3 領域にまたがるものが 4 例であった。 ま た 9 例は小鹪中心， 4 例は全周，後壁中心は 2 例，前 壁中心は 1 例のみであった。肉眼型は 3 型が 8 例と最 も多く，次いで 4 型 7 例， 2 型 1 例であった．組織型 は por 5 例, sig 4 例, muc 2 例, tubl 2 例, tub2 1 例, pap 1 例, 内視鏡生検での診断のつかなかったスキル スタイプ1例であった。

\section{2. 画像診断と腹腔鏡診断との乘離}

各症例の臨床病理学的背景因子および術前 CT, 胃 透視，胃内視鏡等の画像診断による進行度診断と腹腔 鏡による進行度診断を表 2 に示す. $\mathrm{P}, \mathrm{T}, \mathrm{N}, \mathrm{H} 4$ 種 類の因子の腹腔鏡検査施行前後における診断について 16症例中，11症例15因子で乘離がみられた．進行度の 比較では，腹腔鏡検査後に down staging の見られた もの 3 例 (18.8\%), up stagingの見られたもの 4 例

表 2 腹腔鏡診断を施行した進行胃癌症例

\begin{tabular}{|c|c|c|c|c|c|c|c|}
\hline 症例 & 年齢 & 性 & 占拋部位 & 肉眼型 & 組織型 & 画像䛦断によるステージ & 腹腔鏡によるステージ \\
\hline 1 & 44 & F & CME /小 & 4 & muc & Stage IV b /T4P1H0N3M0 & Stage IV a /T3P0 \\
\hline 2 & 38 & F & $\mathrm{C} /$ 小 & 3 & por & Stage IV b /T2P2H0N0M0 & /T3P3 \\
\hline 3 & 44 & F & CM /全 & 4 & sig & Stage $I N \mathrm{~b} / \mathrm{T} 4 \mathrm{P} 1 \mathrm{H} 0 \mathrm{~N} 4 \mathrm{Ml}$ & /T3 \\
\hline 4 & 67 & M & MCA /小 & 3 & por & Stage IV $b / T+P 0 H 0 N+N 1$ & /T3P3H1 \\
\hline 5 & 63 & $\mathrm{~F}$ & MCA /小 & 3 & tub1 & Stage IV b / T3P0H0N4M0 & / \\
\hline 6 & 56 & $\mathrm{~F}$ & $\mathrm{MC}$ /小 & 4 & por & Stage IV b $/ \mathrm{T} 3 \mathrm{P} 0 \mathrm{H} 0 \mathrm{~N} 4 \mathrm{M} 0$ & $/ \mathrm{P} 2$ \\
\hline 7 & 57 & M & MA /後 & 2 & pap & Stage III a /T3P0H0N $1 \mathrm{M} 0$ & Stage II /T2 \\
\hline 8 & 65 & M & $\mathrm{MAC} /$ 小 & 3 & por & Stage III a $/ \mathrm{T} 3 \mathrm{P} 0 \mathrm{H} 0 \mathrm{~N} 2 \mathrm{M} 0$ & / \\
\hline 9 & 57 & $\mathrm{~F}$ & /小 & 3 & tubl & Stage IV a /T3P0H0N3M0 & 1 \\
\hline 10 & 65 & M & /前 & 3 & tub2 & Stage II /T3P0H0N0M0 & Stage III a /N1 \\
\hline 11 & 70 & F & MA /小 & 3 & muc & Stage Ill b /T3P0H0N2M0 & Stage III a $/ \mathrm{T} 2$ \\
\hline 12 & 77 & M & MCA /小 & 3 & por & Stage Ill a /T3P0H0N1M0 & 1 \\
\hline 13 & 48 & $\mathrm{~F}$ & M / / 全 & 4 & sig & Stage II /T3P0H0N0M0 & Stage IV a /P1 \\
\hline 14 & 27 & F & $\mathrm{CM}$ & 4 & unknown & Stage II $/$ T3P0H0NOM0 & 1 \\
\hline 15 & 51 & M & MA & 4 & sig & Stage II /T3P0H0N0M0 & Stage IV b /P3 \\
\hline 16 & 44 & M & $\mathrm{CM}$ & 4 & sig & Stage Ill a /T3P0H0N1M0 & Stage IV b /P3 \\
\hline
\end{tabular}


$(25.0 \%)$, stage の変わらなかったもの 9 例 $(56.3 \%)$ であった.

次に各因子別に画像検査と腹腔鏡検査との乘離を検 討した（表 3)。まずT因子に関しては全体で 6 例 (37.5\%) の不一致を見た。このうち 5 例 $(31.3 \%)$ は 画像診断が浸潤程度を過大評価していた，P因子に関 しては，16例中 7例 $(43.8 \%)$ に不一致が見られた. このうち 6 例 (37.5\%) は画像診断で指摘できなかっ

\section{表 3 各因子別の画像診断と腹腔鏡診断との乘離}

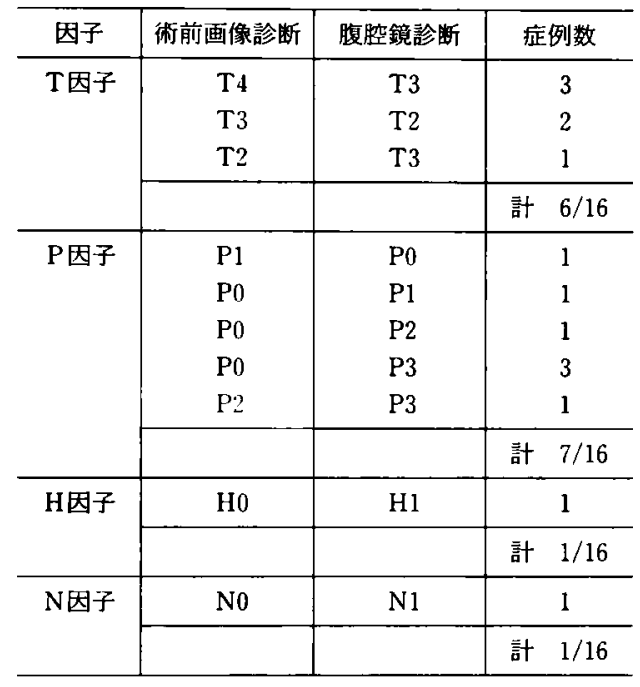

た微小な腹膜播種が腹腔鏡で見つかったものであっ た。組織型で見るとこれら 5 例は全例 sig または por

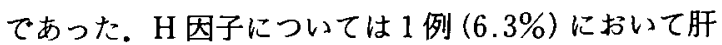
表面の微小な転移巣が腹腔鏡で確認された。 $\mathrm{N}$ 因子に ついては4dのリンパ節の腫大が腹腔鏡検査で見つ かったものが 1 例 (6.3\%) あった. 画像診断と腹腔鏡 診断とが完全に一致した症例は 5 例 $(31.3 \%)$ であっ た.

\section{3. 腹腔内洗浄細胞診および生検について}

表 4 に示すように，16例中14例に腹腔鏡下に腹腔内 洗浄細胞診を施行した。うち 5 例は class $\mathrm{V}$ と診断さ れた.また 22 以上の腹膜播種例 5 例に腹腔鏡下に生検 を行ったが，全例に組織学的に転移が認められた。

\section{4. 腹腔鏡検查後の治療}

表 5 の如く16例中 8 例 $(50 \%)$ は腹腔鏡診断後，治 瘾切除可能と判断し手術を施行した. 8 例全例に根治 度 B 以上の手術が可能であった. 残りの8例は, 初回 根治手術不可能と診断し neoadjuvant chemotherapy を施行した.このうち 2 例に chemotherapy 後, 切除 術を行った. 初回根治切除不能とした 8 例のうち 4 例 (25.0\%) は術前画像診断のみでは十分治瘾切除可能と 考えられたが腹腔鏡検查が見つかり非排除となった。 残り 4 例のうち 2 例は $\mathrm{M}(+)$ のため, 1 例は大動脈 周囲のリンパ節転移が高度のため， 1 例は 12 番リンパ 節転移巣から門脈内への浸潤があり術前画像検査のみ

表 4 洗浄細胞診および生検の結果

\begin{tabular}{|c|c|c|c|c|c|}
\hline 症例 & 腹腔鏡診断 & 洗浄細胞診の有無 & 結果 & 生検の有無 & 結果 \\
\hline 1 & T3P0 & 有 & class $\mathrm{V}$ & 無 & - \\
\hline 2 & T3P3 & 有 & class II & 有 & metastasis \\
\hline 3 & T3Pl & 有 & class $\mathrm{V}$ & 無 & - \\
\hline 4 & T3P3 & 無 & - & 有 & metastasis \\
\hline 5 & $\mathrm{~T} 3 \mathrm{P} 0$ & 有 & class II & 無 & - \\
\hline 6 & T3P2 & 有 & class I & 有 & metastasis \\
\hline 7 & $\mathrm{~T} 2 \mathrm{P} 0$ & 有 & class I & 無 & - \\
\hline 8 & T3P0 & 無 & - & 無 & - \\
\hline 9 & T3P0 & 有 & class I & 無 & - \\
\hline 10 & T3P0 & 有 & class I & 無 & - \\
\hline 11 & $\mathrm{~T} 2 \mathrm{P} 0$ & 有 & class II & 無 & - \\
\hline 12 & T3P0 & 有 & class V & 無 & - \\
\hline 13 & T3P1 & 有 & class $\mathrm{V}$ & 無 & - \\
\hline 14 & T3P0 & 有 & class I & 無 & - \\
\hline 15 & T3P3 & 有 & class $\mathrm{V}$ & 有 & metastasis \\
\hline 16 & T3P3 & 有 & class IV & 有 & metastasis \\
\hline & & \multirow{2}{*}{\multicolumn{2}{|c|}{$\begin{array}{r}\text { 洗浄細胞揨施行例 } 14 \text { 例 } \\
\text { 陽性例 } 5 \text { 例 }\end{array}$}} & \multirow{2}{*}{$\begin{array}{r}\text { 生検施行例 } \\
\text { 陽性例 }\end{array}$} & 5 例 \\
\hline & & & & & 5 例 \\
\hline
\end{tabular}


表 5 腹腔鏡後の治療

\begin{tabular}{c|c}
\hline 全症例数 & $16(100.0 \%)$ \\
\hline 手術単独 & $8(50.0 \%)$ \\
\hline 根治度 $\mathrm{A}$ & $0(0.0 \%)$ \\
根治度 B & $8(50.0 \%)$ \\
根治度 C & $0(0.0 \%)$ \\
\hline 術前化学療法+手術 & $2(12.5 \%)$ \\
\hline 根治度 $\mathrm{A}$ & $0(0.0 \%)$ \\
根治度 B & $2(12.5 \%)$ \\
根治度 C & $0(0.0 \%)$ \\
\hline 化学療法単独 & $6(37.5 \%)$ \\
\hline
\end{tabular}

表 6 手術例 8 例における腹腔鏡診断の正診率

\begin{tabular}{|c|c|c|c|}
\hline 症例 & 腹腔鏡診断 & 手術学的進行度 & 相違の理由 \\
\hline 1 & T3 & $\mathrm{T} 4$ & 肝左葉外側, 膵尾への浸潤 \\
\hline 7 & $\mathrm{~T} 2$ & T3 & 胃体部後壁の繁膜浸潤 \\
\hline 8 & T3 & $\mathrm{T} 4$ & 脺への浸潤 \\
\hline 10 & N1 & $\mathrm{N} 2$ & リンパ節転移 \\
\hline 11 & $\mathrm{~T} 2$ & $\mathrm{~T} 3$ & 後壁の墏膜浸潤 \\
\hline 12 & T3 & $\mathrm{T} 4$ & 結腸間膜後面への浸潤 \\
\hline 13 & N1 & N4 & リンパ節転移 \\
\hline 14 & T3 & $\mathrm{T} 4$ & 横行結腸への浸潤 \\
\hline
\end{tabular}

で手術適応がないことが明らかであった。

また初回治瘜切除可能と診断し手術を施行した 8 例 において手術的進行度と腹腔鏡診断とを比較すると表 6 のように 6 例 $(75.0 \%) に \mathrm{~T}$ 因子で相違がみられた。 これらは全て腹腔鏡猃断が過小評価していたもので， このうち 5 例 $(62.5 \%)$ は胃後壁の情報の見落としに よるものであった。また N 因子の過小評価も 2 例 (25.0\%) に見られた。

\section{5. その他}

16例中 9 例 (62.5\%) は局所麻酔下に行ったが，特 に疼痛のため検查を中止したり，術中術後に合併症等 の問題は見られなかった。

\section{考察}

これまで腹腔内の固形腫瘍に対する腹腔鏡検査とし ては婦人科領域において最も精力的に行われてお $\eta^{778)}$, 特に卵巣腫晹では組織診断のみならず病変の広 がりの検索にも有用であると考えられている.

胃癌に対する術前腹腔鏡検査に関しては，あまり多 くの報告はないが, Watt らは9", 90例の食道癌と胃癌 症例に腹腔鏡検査を行った結果，CT や超音波エコー 等の従来の画像診断に比ベリンパ節転移と腹膜播種の 診断については腹腔鏡検査の方が sensitivity, accu- racyとも有意に良好であったと報告している，また Kriplani らは(10)切除可能と診断されていた40例の胃 癌患者に腹腔鏡検查を行ったが，5例（12.5\%）は遠 隔転移のため，11例（27.5\%）は局所浸潤が高度のた め切除不能と診断され，結果的に16例 $(40 \%)$ に不必 要な開腹術が回避できたとしていずれの報告も腹腔鏡 検查が有用であると結論している．今回，われわれが 対象とした16例の胃癌患者はいずれも術前画像検査で T3または $\mathrm{P}(+)$ の疑われた高度進行胃癌ばかりであ り, 前述の報告とは背景因子が異なっているが, 画像 検査と腹腔鏡検查の結果が全ての因子で完全に一致し たのはわずか 5 例 (31.3\%) であり，残りの約 $70 \% の$ 症例においては腹腔鏡検查を行った結果から何らかの 新しい情報が得られたわけであり，他家の報告と同様， 腹腔鏡検查は非常に有効であるといえる.

新しく得られた情報のうち主なものは $\mathrm{P}$ 因子と $\mathrm{T}$ 因子に関するものであった，P因子に関しては，本来 CT 等の画像検査だけでは診断に限界があるのは当然 であるが，実に16例中 7例 (43.8\%) に不一致が見ら れ，そのほとんどは画像検查で指摘できなかった微小 な腹膜播種が腹腔鏡で見つかったものであった。組織 型で見ると全例 sig または porで，これらの組織型の 腫瘍の場合, 特に腹腔鏡検查による腹膜播種の検索が 必要と思われる。次に T 因子に関してであるが, 従来 の画像診断の中では超音波内視鏡が深達度診断におい ては压倒的な accuracyの良さを誇っており，CTの 15 44\%に対し超音波内視鏡は80 92\%の overall の accuracy があると報告されている"1).しかしこれらの データはかなり熟練した内視鏡医のいる施設のもので あり，また T2と T3の判別が最も難しいとされており まだまだ十分な情報を与えてくれるものではない，腹 腔鏡検查は T 因子の診断, とくに T2と T3の織別に非 常に有効な因子と言われている ${ }^{12)}$.

今回われわれの行った16例の検討では, 初回手術症 例 8 例の手術的進行度診断を術前の腹腔鏡診断と比較 した結果，6例で T因子の診断に誤りが見られた.い ずれの場合も大きな誤りではなく絶対的非治瘑切除と なった症例はなかった，そのほとんどが後壁の深達度 の診断の誤りによるもので, 腫瘍が大きくその主占拠 部位が広範囲にまたがる場合は，浸潤の疑われる部位 をすべて腹腔鏡で直視下に観察することが非常に困難 であり診断の精度という点ではまだまだ問題がある。

スコープを網亳内に挿入し後壁を観察するという報

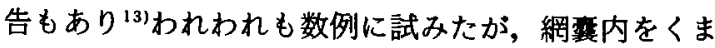


なくするのは困難であり，また局所麻酔下での観察は 苦痛が強いため, 今後は硬膜外麻西等の併用による十分 な鎮痛や超音波内視鏡の併用等を考慮する必要がある と思わ机た。

洗浄細胞診の陽性率は14例中 5 例 (35.7\%) で, 腹 膜播種がある症例ですへて陽性になるわけでなく逆に 腹膜播種の見られない症例でも陽性になる例が少なか らず存在した. 洗浄細胞診の意義については, Bokuら は14), 胃癌の槳膜浸潤と腹腔内遊離癌細胞の存在は重 要な予後規定因子であると言っており，Nekardaら

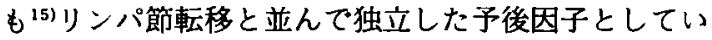
3.

また，免疫組織学的染色 ${ }^{15}$ や洗浄液の CEA を測定

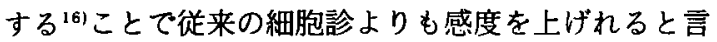
う報告もあるが，いずれにしても腹腔鏡検査によりこ れらの情報が得られることの意義は大きいと思われ 3.

以上, 高度進行胃癌に対する術前腹腔鏡の有用性と 問題点について述べた. 将来的には解像度の優れた細 径の内視鏡の登場によりさらに低侵奘性の検査となり ルーチン化するものと思われる．今後ますます多様化 していくであろう胃癌の集学的治療にとって正確なス テージ診断や治療効果の判定は必須のものであり,さ らには分子生物学的手法を用いた癌の進行度診断や悪 性度診断のためのサンプリングの手段としても有用と なるであろう。

\section{結 論}

1. 高度進行胃癌患者に対する腹腔鏡検査は安全か つ容易に行え, 手術適応の決定や化学療法の効果判定 に有効であると考えられた。

2. 胃後壁側の腫場の浸潤やリンパ節転移に関する 診断率の向上については今後検討が必要であると思わ れた。

\section{References}

1) Viste A, Haugstvedt T, Eide E, et al: Postoperative complications and mortality after surgery for gastric cancer. Ann Surg $207: 7-13$, 1988

2) Hallissey MT, Allum WH, Roginski C, et al: Palliative surgery for gastric cancer. Cancer 62: 440-444, 1988

3) Valen $B$, Viste A, Haugstvedt $T$, et al : Treatment of stomach cancer, a national experience. Br J Surg 75 : 708-712, 1988
4) Irvin TT, Bridger JE: Gastric cancer: An audit of 122 consecutive cases and the results of rl gastrectomy. Br J Surg 75: 106-109, 1988

5) Wilke H, Preusser P, Fink U, et al: Preoperative chemotherapy in locally advanced and nonresectable gastric cancer: A phase II study with etoposide, doxorubicin and cisplatin. J Clin Oncol 7 : 1318-1326, 1989

6) Plukker JT, Mulder NH, Sleijfer DTH, et al: Chemotherapy and surgery for locally advanced cancer of the cardia and fundus: Phase II study with methotrexate and 5fluorouracil. Br J Surg 78 : 955-958, 1991

7) Mage G, Wattiez A, Canis M, et al: Contribution of celioscopy in the early diagnosis of ovarian cancers. Ann Chirurg $45: 525-528,1991$

8) Martin DC: Laparoscopic treatment of ovarian endometriomas. Clin Obstet Gynecol $34: 452$ $-459,1991$

9) Watt I, Stewart I, Anderseon D, et al : Laparoscopy, ultrasound and computed tomography in cancer of the oesophagus and gastric cardia : A prospective comparison for detecting intraabdominal metastases. Br J Surg 76: 10361039, 1989

10) Kriplani AK, Kapur BML: Laparoscopy for pre-operative staging and assessment of operability in gastric carcinoma. Gastrointest Endosc $37: 441-443,1991$

11) Sendler A, Dittler HJ, Feussner $H$, et al: Preoperative staging of gastric cancer as precondition for multimodal treatment. World $\mathbf{J}$ Surg 19: 501-508, 1995

12) Dittler HJ, Siewert JR: Role of endoscopic ultrasonography in gastric carcinoma. Endos. copy 25: 162-166, 1993

13) Asencio-Arana F : Laparoscopic access to the lesser sac in gastric cancer staging. Surg Laparosc Endosc 4: 438-440, 1994

14) Boku T, Nakane $Y$, Minoura $T$, et al: Prog. nostic significancer of serosal invasion and free intraperitoneal cancer cells. Br J Surg 77 : 436439, 1990

15) Nekarda H, Schenk U, Ludwig C, et al: Prognosis of free abdominal cancer cells in totally resected gastric cancer. Eur J Surg Oncol 20: 
361,1994

16) Asao T, Fukuda T, Y'azawa S, et al: Carcinoembryonic antigen levels in peritoneal washings can predict peritoneal recurrence after curative resection of gastric cancer. Cancer $68: 44--47.1991$

\title{
LAPAROSCOPIC STAGING FOR ADVANCED GASTRIC CANCER
}

\author{
Masahiko YANO, Hitoshi SHIOZAKI, Atsuo MURATA, Masatoshi INOUE, \\ Mitsugu SEKIMOTO, Yuichirou DOKI, Masaaki TANIGUCHI \\ and Morito MONDEN \\ Department of Surgery II, Osaka University Medical School
}

Preoperative laparoscopy was performed in 16 patients with advanced gastric cancer, whose lesions had been diagnosed by conventional examination to be more than $\mathrm{T} 3$ or to have peritoneal seeding, and its usefulness was assessed. After insertion of two trocars, one from the site below the umbilicus and another from the left upper abdomen, the abdominal cavity was inspected, and biopsy and/or abdominal lavage sampling was performed, if necessary. The discrepancy rate of diagnosis in each category between conventional imaging techniques and laparoscopy was $6 / 16(37.5 \%)$ in $\mathrm{T}$ category, $7 / 16(43.8 \%)$ in $\mathrm{P}$ category, $1 / 16(6.3 \%)$ in $\mathrm{H}$ category and $1 / 16(6.3 \%)$ in $\mathrm{N}$ category. Based on these results, down-staging was seen in $3 / 16(18.8 \%)$, up-staging was in $4 / 16(25.0 \%)$ and no change was in $9 / 16(56.3 \%)$ after laparoscopic diagnosis. Laparoscopic examination suggested the resectability of gastric cancer in eight out of 16 patients and all the eight patients underwent curative resection. In the remaining eight primarily inoperable patients, four patients was found to be inoperble by laparoscopic ecamination and could avoid unnecessary laparotomy. In conclusion, it is considered that laparoscopy is a useful preoperative examination for advanced gastric cancer. 